\title{
Growth indexes of Pennisetum purpureum cv. Roxo cultivated in different seasons under rainfed conditions
}

\section{Índices de crescimento do Pennisetum purpureum cv. Roxo cultivado em diferentes épocas sob regime de sequeiro}

MARANHÃO, Theyson Duarte ${ }^{1 *} \mathbb{0}$; LOPES, Marcos Neves²0; ALVES, Francisco Gleyson da Silveira ${ }^{2}$; SILVA, Rafael Rodrigues da ${ }^{2}{ }^{-}$; POMPEU, Roberto Cláudio Fernandes Franco ${ }^{3}$; SOUSA, Wesley do Nascimento ${ }^{2}$; ; LACERDA, Gabriela Florencioº; ${ }^{\circ}$ CÂNDIDO, Magno José Duarte ${ }^{2}$

${ }^{1}$ Departamento de Zootecnia, Escola Superior de Agricultura "Luiz de Queiroz", Universidade de São Paulo-USP, Piracicaba/SP-Brasil

${ }^{2}$ Departamento de Zootecnia, Universidade Federal do Ceará-UFC, Fortaleza/CE-Brasil

${ }^{3}$ Embrapa Caprinos e Ovinos, EMBRAPA/Sobral, CE-Brasil

*Endereço para correspondência: theysonduarte@gmail.com

\begin{abstract}
The objective was to estimate the growth indexes of elephant grass cv. Roxo managed under rainfed conditions in different growing seasons. Seven growth ages $(9,18,27,36,45,54$, and 63 days) were evaluated in three growing seasons (rainy, transition and dry). A completely randomised design was adopted, with splitplot arrangement with time repeated measures, with the ages being the plots and the seasons the subplots. Interaction of age $x$ season was observed. The specific leaf area mean was $0.0286 \pm 0.0039$ during the rainy season. In the transition season, it adjusted to a third-degree polynomial model; in the dry season it declined linearly $\left(0.0003 \mathrm{~m}^{2} \mathrm{~g}^{-1}\right)$. The leaf weight ratio adjusted to the third-degree polynomial model in the rainy and dry seasons, and in the transition season it was maximised at 28 DAC $\left(0.694 \mathrm{~g} \mathrm{~g}^{-1}\right)$. The leaf area ratio continuously declined in the rainy season. In the transition and dry seasons, it adjusted to the third-degree polynomial model. The net assimilation rate presented averages of $3.73 \pm 2.50$ and $3.63 \pm 1.48 \mathrm{~g} \mathrm{~m}^{-2}$ day $^{-1}$ in the rainy and transition seasons, respectively. In the dry season, it was minimised at 48.4 days. The relative growth rate mean was $0.0075 \pm 0.0037$ during the rainy season. In the transition and dry seasons, it adjusted to the third-degree
\end{abstract}

polynomial model. The growth index rates of elephant grass cv. Roxo are modified by growing seasons, and the pattern and magnitude of the response varies throughout the growth cycle.

Keywords: Elephant grass, net assimilation rate, relative growth rate, seasonality

\section{RESUMO}

Objetivou-se estimar os índices de crescimento do capim-elefante $\mathrm{cv}$. Roxo manejado sob sequeiro em diferentes épocas de cultivo. Analisaram-se sete idades de crescimento $(9 ; 18 ; 27 ; 36 ; 45 ; 54$ e 63 dias) em três épocas de cultivo (chuvosa, transição e seca). Adotou-se delineamento inteiramente casualizado em arranjo de parcelas subdivididas no tempo, com as idades sendo alocadas nas parcelas e as épocas de cultivo nas subparcelas. Constatou-se interação idade x época de cultivo. A área foliar específica revelou média de $0,0286 \pm 0,0039$ na época chuvosa. Na época de transição ajustou-se ao modelo polinomial de terceiro grau e na época seca reduziu linearmente $\left(0,0003 \mathrm{~m}^{2} \mathrm{~g}^{-1}\right)$. A razão de peso foliar ajustou-se ao modelo polinomial de terceiro grau nas épocas chuvosa e seca e na época de transição foi maximizada aos $28 \mathrm{DAC}$ $\left(0,694 \mathrm{~g} \mathrm{~g}^{-1}\right)$. A razão de área foliar reduziu 
continuamente na época chuvosa. Já nas épocas de transição e seca ajustou-se ao modelo polinomial de terceiro grau. A taxa de assimilação líquida apresentou médias de $3,73 \pm 2,50$ e $3,63 \pm 1,48 \mathrm{~g} \mathrm{~m}^{-2} \mathrm{dia}^{-1}$ para as épocas chuvosa e de transição, respectivamente. $\mathrm{Na}$ época seca, foi minimizada aos 48,4 dias. A taxa de crescimento relativo apresentou média de $0,0075 \pm 0,0037$ na época chuvosa. Nas épocas de transição e seca ajustou-se ao modelo polinomial de terceiro grau. Os índices de crescimento do capim-elefante cv. Roxo são modificados pelas épocas de cultivo e o padrão e a magnitude da resposta variam ao longo do ciclo de crescimento.

Palavra chaves: Capim-elefante, sazonalidade, taxa de assimilação líquida, taxa de crescimento relativo. 


\section{INTRODUCTION}

Water restriction is among the main causes of anti-productivity abiotic stress in global agricultural crops (PENNISI, 2008). With the increase in the vulnerability of agricultural production due to the expansion of semiarid areas and the increase in the global demand for animal products, it is necessary to adopt strategies that make animal production feasible in semiarid regions (MARENGO, 2008; IPCC, 2014).

The development and growth of the forage plant vary according to the growth stage, species, cultivar and availability of abiotic growth factors (DARTORA et al., 2013; MOREIRA et al., 2015; MARANHÃO et al., 2018a). It is emphasised that rainfall is the main abiotic modulator of growth of forages under rainfed conditions, since it is commonly seen as an abiotic factor that is more limiting to plant growth and development in semiarid regions.

The use of forage plants tolerant of water restriction is one of the effective actions to make viable the production of ruminants in semiarid environments. Species of the genus Pennisetum are important forage resources for tropical agricultural systems, since they have high productive potential and agronomic attributes that make them tolerant to water deficit.

Among the species of the genus Pennisetum, elephant grass $(P$. purpureum) cv. Roxo stands out for having rhizomes that have the capacity to store water and organic solutes, and also for having anthocyanins in the leaf blades, which minimise the deleterious effects of excessive solar radiation and water deficit on carbon assimilation (ARAÚJO \& DEMINICIS, 2009). Such agronomic characteristics demonstrate the potential of this forage for the tropical agricultural systems that are vulnerable to seasonal rainfall.

Studies of growth analysis considering elephant grass cultivars are scarce in the literature, especially for forage managed under rainfed conditions. Thus, it is clear that there is a demand for research on growth analysis of forage plants grown in tropical regions, considering rainfall variation, mainly for elephant grass cv. Roxo. Therefore, the objective in this study was to establish the growth curves of elephant grass cv. Roxo cultivated under rainfed conditions in three growing seasons.

\section{MATERIALS AND METHODS}

The study was carried out at the Animal Science Department of the Federal University of Ceará NEEF/DZ/CCA/UFC, in Fortaleza - CE (latitude $03^{\circ} 44^{\prime} \quad 32 "$ south and longitude $38^{\circ} 34^{\prime} \quad 40^{\prime \prime}$ west). The climate of the region was classified as type Aw', tropical rainy, according to Köppen (1936). The study used an area of elephant grass (Pennisetum purpureum) cv. Roxo established about five years prior to the study, in a yellowish Argissol soil with sandy texture (SANTOS et al., 2013). The forage plant was evaluated during three successive growth cycles in different seasons (rainy, transition and dry). The seasons were characterised according to the rainfall quantified during the experimental period (Figure 1).

Cumulative rainfall of $373.3,17.3$ and $9.6 \mathrm{~mm}$ was quantified in the rainy, transition and dry seasons, respectively. The potential evapotranspiration of the crop presented a daily average of 39.4, 46.1 and $52.6 \mathrm{~mm} \mathrm{day}^{-1}$ for rainy, transition and dry seasons, respectively. The climatological variables were obtained at the Agroclimatological 
Station of the Federal University of

Ceará, Pici Campus (Figure 1).

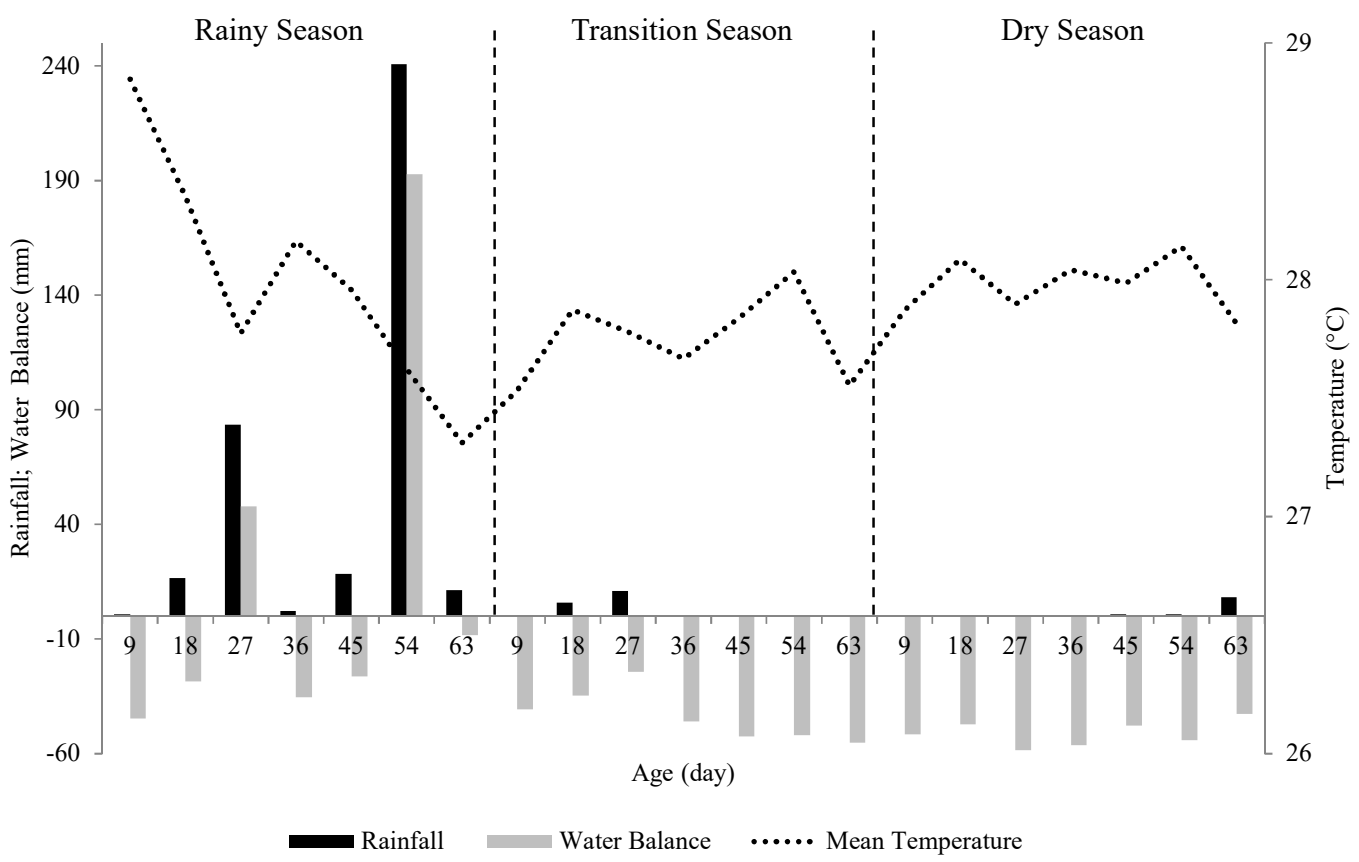

Figure1. Climatic data for the experimental period

Seven growth ages $(9,18,27,36,45$, 54 , and 63 days after cutting) and three growing seasons (rainy, transition and dry) were studied in $3.0 \times 3.5 \mathrm{~m}$ $\left(10.5 \mathrm{~m}^{2}\right)$ experimental plots. A completely randomised design was adopted, with split-plot arrangement with time-repeated measures, with the ages being the plots and the growing seasons the subplots, with three replicates.

A soil sampling was performed in the 0 to $0.20 \mathrm{~m}$ surface layer before the experimental period began. The analysis of the sample revealed the following chemical attributes: $\mathrm{pH}$ in water 6.0; $20.89 \mathrm{~g} \mathrm{~kg}^{-1} \quad$ O.M.; $397 \quad$ and $3.91 \mathrm{mg} \mathrm{dm}^{-3}$ of $\mathrm{P}$ and $\mathrm{K}$, respectively; $2.8,1.5,0.15$ and $0.04 \mathrm{cmolc} \mathrm{dm}^{-3}$ of $\mathrm{Ca}^{2+}, \mathrm{Mg}^{2+}, \mathrm{Al}^{3+}$ and $\mathrm{Na}^{+}$, respectively. From these data, maintenance fertilisation was carried out according to the recommendation of CFSEMG (1999), at the beginning of the rainy season. At the end of each growing season, a soil chemical analysis $(0-0.20$ $\mathrm{m}$ layer) was performed to characterise its fertility (Table 1).

Table 1. Chemical soil attributes at the end of each cultivation season of elephant grass cv. Roxo

\begin{tabular}{|c|c|c|c|c|c|c|c|c|c|c|c|}
\hline \multirow{2}{*}{ Season } & $\mathrm{P}$ & $\mathrm{K}$ & $\mathrm{Ca}^{2+}$ & $\mathrm{Mg}^{2+}$ & $\mathrm{Al}^{3+}$ & $\mathrm{Na}^{+}$ & SB & $\mathrm{T}$ & \multirow{2}{*}{$\frac{\mathrm{OM}}{\mathrm{g} \mathrm{kg}^{-1}}$} & \multirow{2}{*}{$\begin{array}{c}\mathrm{V} \\
\%\end{array}$} & \multirow{2}{*}{$\frac{\mathrm{pH}}{\mathrm{H}_{2} \mathrm{O}}$} \\
\hline & \multicolumn{2}{|c|}{-----mg dm $\mathrm{dm}^{-3}----$} & \multicolumn{6}{|c|}{ 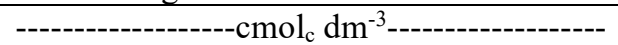 } & & & \\
\hline Rainy & 179.0 & 58.6 & 3.8 & 2.3 & 0.40 & 0.06 & 6.3 & 8.8 & 14.6 & 72 & 5.4 \\
\hline Transition & 177.0 & 39.1 & 2.5 & 2.1 & 0.30 & 0.04 & 4.8 & 6.6 & 10.0 & 73 & 5.9 \\
\hline Dry & 165.0 & 58.7 & 2.8 & 2.3 & 0.40 & 0.05 & 5.3 & 7.1 & 13.7 & 75 & 5.9 \\
\hline
\end{tabular}

Phosphorus (P), potassium (K), calcium $(\mathrm{Ca})$, magnesium $(\mathrm{Mg})$, aluminium $(\mathrm{Al})$, sodium $(\mathrm{Na})$, organic matter $(\mathrm{OM})$, sum of bases $(\mathrm{SB})$, total capacity of cation exchange $(\mathrm{T})$, hydrogen ion potential $(\mathrm{pH})$ 
Doses equivalent to $600 \mathrm{~kg} \mathrm{ha}^{-1}$ year $^{-1}$ of nitrogen (urea), $200 \mathrm{~kg} \mathrm{ha}^{-1}$ of potassium chloride and $50 \mathrm{~kg} \mathrm{ha}^{-1}$ of fritted trace elements (FTE BR 12: $0.42 \mathrm{~kg} \mathrm{ha}^{-1}$ of copper, $1.0 \mathrm{~kg} \mathrm{ha}^{-1}$ of manganese, $4.5 \mathrm{~kg} \mathrm{ha}^{-1}$ of zinc, $1.95 \mathrm{~kg} \mathrm{ha}^{-1}$ of sulphur and $0.90 \mathrm{~kg} \mathrm{ha}^{-1}$ of boron) were adopted. The fertilisers were administered in the beginning of the rainy season (at days 18 and 27), in order to increase the efficiency of their use by the forage, as a result of water availability through rainfall. The fertilisation was divided into two applications - the first one $(100 \%$ of FTE BR-12, $50 \%$ of nitrogen and $50 \%$ of potassium) was carried out at 18 days, and the second one $(50 \%$ of nitrogen and $50 \%$ of potassium) at 27 days.

At each growth age, in the three seasons, a sample of forage biomass contained within a frame of known area $(1.0 \times 1.0 \mathrm{~m})$ was collected and cut at the ground level. The biomass harvested was divided into green leaf blade biomass (GLB), green stem biomass (GSB) and dead material biomass (DMB). Afterwards, they were packed in paper bags and placed in a forced ventilation oven at $55^{\circ} \mathrm{C}$ until they reached constant weight. The pre-dry biomasses of the three fractions were summed up to obtain the total forage biomass (TFB).

In the quantification of the leaf area (LA), an aliquot of 25 leaf blades from GLB was used. These were taken from the median portion of the leaf blade, so that the leaf limb presented a rectangular shape with a defined length of $10 \mathrm{~cm}$; later they were weighed and had their widths measured with a ruler, to obtain the mean value. LA was obtained as the product of the length and the average width, allowing to establish proportionality criteria with the GLB sampled (BENINCASA, 2003).

The specific leaf area (SLA; $\mathrm{m}^{2} \mathrm{~g}^{-1}$ ) was estimated by dividing LA by GLB; the leaf area ratio (LAR; $\mathrm{m}^{2} \mathrm{~g}^{-1}$ ) was estimated by dividing LA by TFB; the leaf weight ratio (LWR; $\mathrm{g}^{1} \mathrm{~g}^{-1}$ ) was estimated by the division of GLB by TFB; the net assimilation rate (NAR; $\mathrm{g} \mathrm{m}^{-2}$ day $^{-1}$ ) was estimated as the quotient of LA and the difference of biomass between the ages reached; and the relative growth rate (RGR; g g $^{-1}$ day $^{-1}$ ) was estimated by multiplying NAR and LAR, according to the methodology proposed by Benincasa (2003).

The data were submitted to analysis of variance, mean comparison test and regression analysis. The interaction age $x$ season was deployed when significant by the F-test $(p<0.05)$. The seasons were compared by the Tukey's test $(\mathrm{p}<0.05)$ and the ages evaluated by regression analysis, where the choice of the models was made taking into account the significance of the coefficients of the models by the F-test $(\mathrm{P}<0.05)$ and the coefficient of determination. Statistical analysis was performed using the software System for Statistical and Genetic Analysis (SAEG 9.1, 2007).

\section{RESULTS AND DISCUSSION}

Interaction $(\mathrm{p}<0.05)$ was observed between the growth ages and growing seasons for all variables studied. The specific leaf area (SLA) showed no adjustment to the models tested in the rainy season $(0.0286 \pm 0.0039)$, presented an increase from age 9 to age 18 days after the cut (DAC), decreased on age 27 DAC and kept constant until $63 \mathrm{DAC}$ (Figure 2B). In the transition period, SLA was maximised at 9 DAC $\left(0.046 \mathrm{~m}^{2} \mathrm{~g}^{-1}\right)$ and minimised at 
$63 \mathrm{DAC}\left(0.039 \mathrm{~m}^{2} \mathrm{~g}^{-1}\right)$. In the dry season, SLA reduced linearly $\left(0.0003 \mathrm{~m}^{2} \mathrm{~g}^{-1} \mathrm{day}^{-1}\right)$ along the growth ages, reaching 0.048 and $0.026 \mathrm{~m}^{2} \mathrm{~g}^{-1}$ day $^{-1}$ at 9 and $63 \mathrm{DAC}$, respectively (Figure 2A).

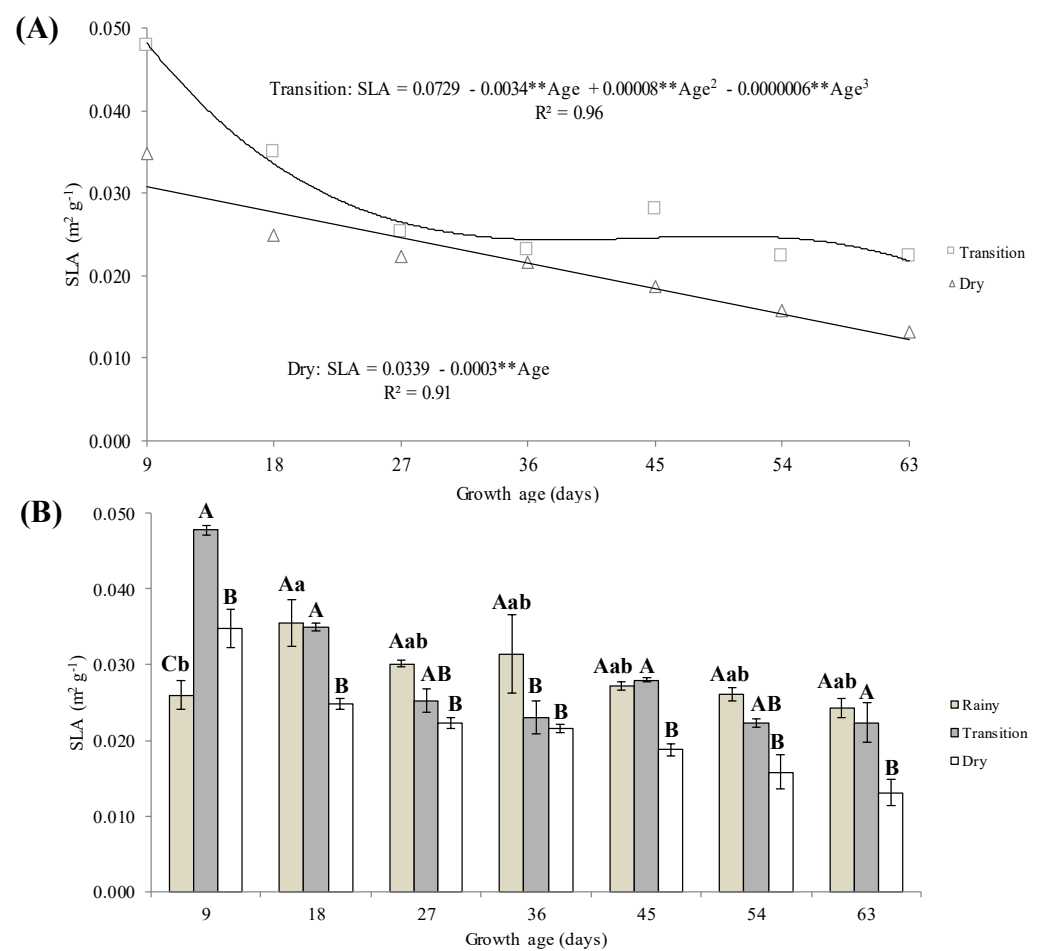

Figure 2. Specific leaf area (SLA); coefficient of determination $\left(\mathrm{R}^{2}\right)$, significant at the level of $1 \%(* *)$. Means followed by the same uppercase letters in the same age do not differ $(p>0.05)$ by the Tukey's test. Means followed by the same lowercase letters in different ages do not differ $(\mathrm{p}>0.05)$ by the Tukey's test.

The reduction of SLA as the canopy grew in the three seasons was due to the allocation of carbon in the midrib of the leaf blades to support their weight as they increased in length and width (SANTOS et al., 2010). This response allows the maintenance of an architectural arrangement favourable to the interception of photosynthetically active radiation by the forage canopy until the end of the plant growth cycle.

Analysing the effect of the growing season on SLA (Figure 2B), in general, higher values were observed in the rainy season, intermediate values in the transition season and lower values in the dry season. The verified response pattern for elephant grass cv. Roxo was due to the reduction of leaf area through the intensification of senescence and foliar abscission processes, in response to water restriction that intensified throughout the growing seasons (Figure 1).

In the rainy season, the LWR was maximised at 19 DAC $\left(0.764 \mathrm{~g} \mathrm{~g}^{-1}\right)$, then progressively reduced, being minimised at $63 \mathrm{DAC} \quad\left(0.336 \mathrm{~g} \mathrm{~g}^{-1}\right)$ (Figure 3A). The higher LWR at the beginning of the growth cycle shows 
that elephant grass cv. Roxo firstly invested its photoassimilates in the increase of leaf biomass in order to restore the photosynthetic leaf area and to provide a more accelerated growth, reaching the linear phase of the curve faster, and thus responding by the incremental increase in the canopy photosynthetic rate.

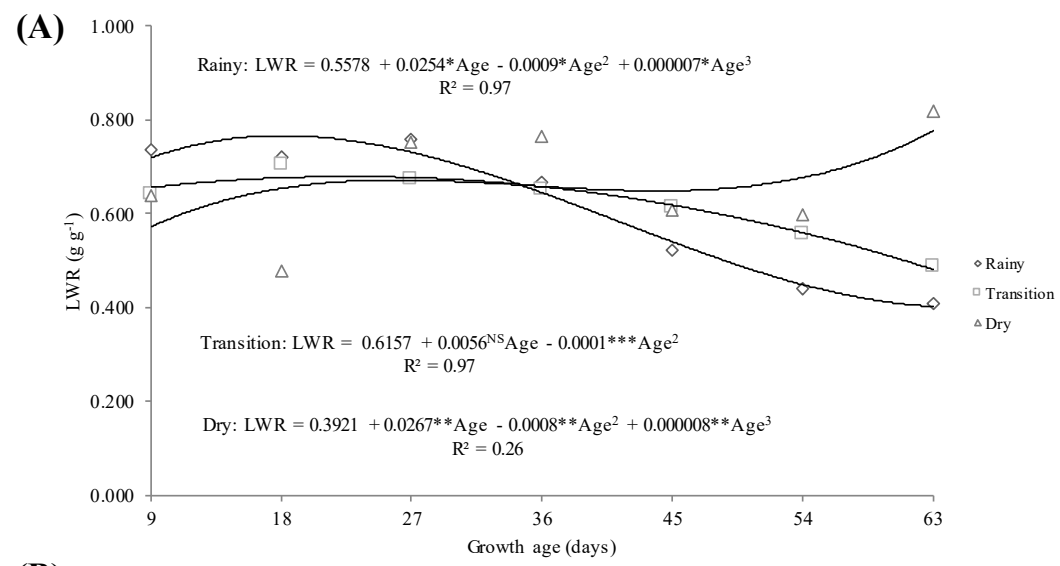

(B)

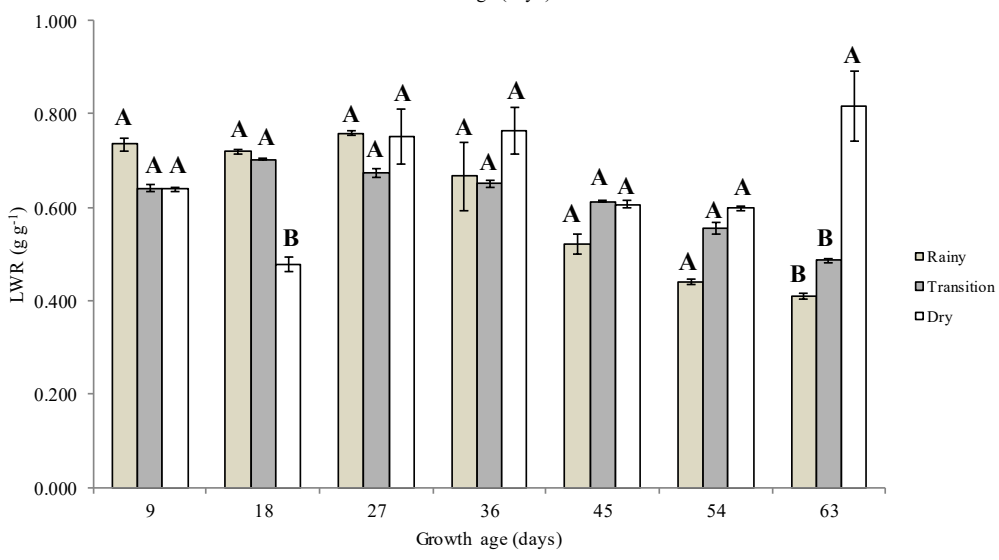

Figure 3. Leaf weight ratio (LWR); coefficient of determination $\left(\mathrm{R}^{2}\right)$, significant at the level of $0.1 \%(* * *), 1 \%(* *)$ and $5 \%(* *)$; non-significant (NS). Means followed by the same uppercase letters in the same age do not differ $(p>0.05)$ by the Tukey's test. Means followed by the same lowercase letters in different ages do not differ $(\mathrm{p}>0.05)$ by the Tukey's test.

The reduction of LWR from 19 DAC indicates a change in carbon allocation. Probably, the stem was the main drainage organ of elephant grass cv. Roxo, and this hypothesis is corroborated by the linear reduction in the leaf blade/stem ratio observed at that time.

In the transition season, the LWR was maximised at 28 DAC $\left(0.694 \mathrm{~g} \mathrm{~g}^{-1}\right)$, reducing thereafter until the last age studied. The reduction in LWR coincided with the end of rainfall at that time (Figure 1). Probably, the root system was configured as the main photoassimilate drain in order to increase the agronomic efficiency regarding the soil water absorption at deeper horizons (DONG et al., 2012). 
In the dry season, LWRs of 0.573 and $0.899 \mathrm{~g} \mathrm{~g}^{-1}$ were estimated at ages 9 and 63 DAC, respectively. An increase of LWR was observed from 45 to 63 DAC, as a result of the occurrence of rainfall (Figure 1). This response highlights the potential of elephant grass cv. Roxo for cultivation under a rainfed regime, as it proved to be efficient in the use of rainfall for the increase of leaf blade biomass at the expense of its total forage biomass, a good characteristic in forage plants managed under rainfed conditions.

Regarding the effect of the growing season, it was observed that LWR differed $(p<0.05)$ only at 18 and 63 DAC. The similarity in LWR between growing seasons at most ages reveals that the increase of leaf biomass in relation to the increment of total forage biomass was not altered, despite the reduction in its SLA (Figure 2B), probably due to the progressive reduction of water availability (Figure 1).

The LWR response between growing seasons demonstrates the ability of elephant grass cv. Roxo to keep the distribution of the assimilated carbon to the leaf blade component in relation to shoot biomass, regardless of the availability of rainfall (Figure 1). This is a significant characteristic for forage managed under water deficit, since there is usually a reduction in leaf biomass as a response to stress due to water deficit (PINCELLI \& SILVA, 2012; TAIZ et al., 2017).

There was an effect of the growth ages on the leaf area ratio (LAR) $(\mathrm{p}<0.05)$ in the three seasons studied. For ages 9 and $63 \mathrm{DAC}$, values of 0.032 and $0.027 \mathrm{~m}^{2} \mathrm{~g}^{-1}$ (rainy season), 0.031 and $0.015 \mathrm{~m}^{2} \mathrm{~g}^{-1}$ (transition season), and 0.021 and $0.006 \mathrm{~m}^{2} \mathrm{~g}^{-1}$ (dry season) were estimated, respectively, (Figure 4A).
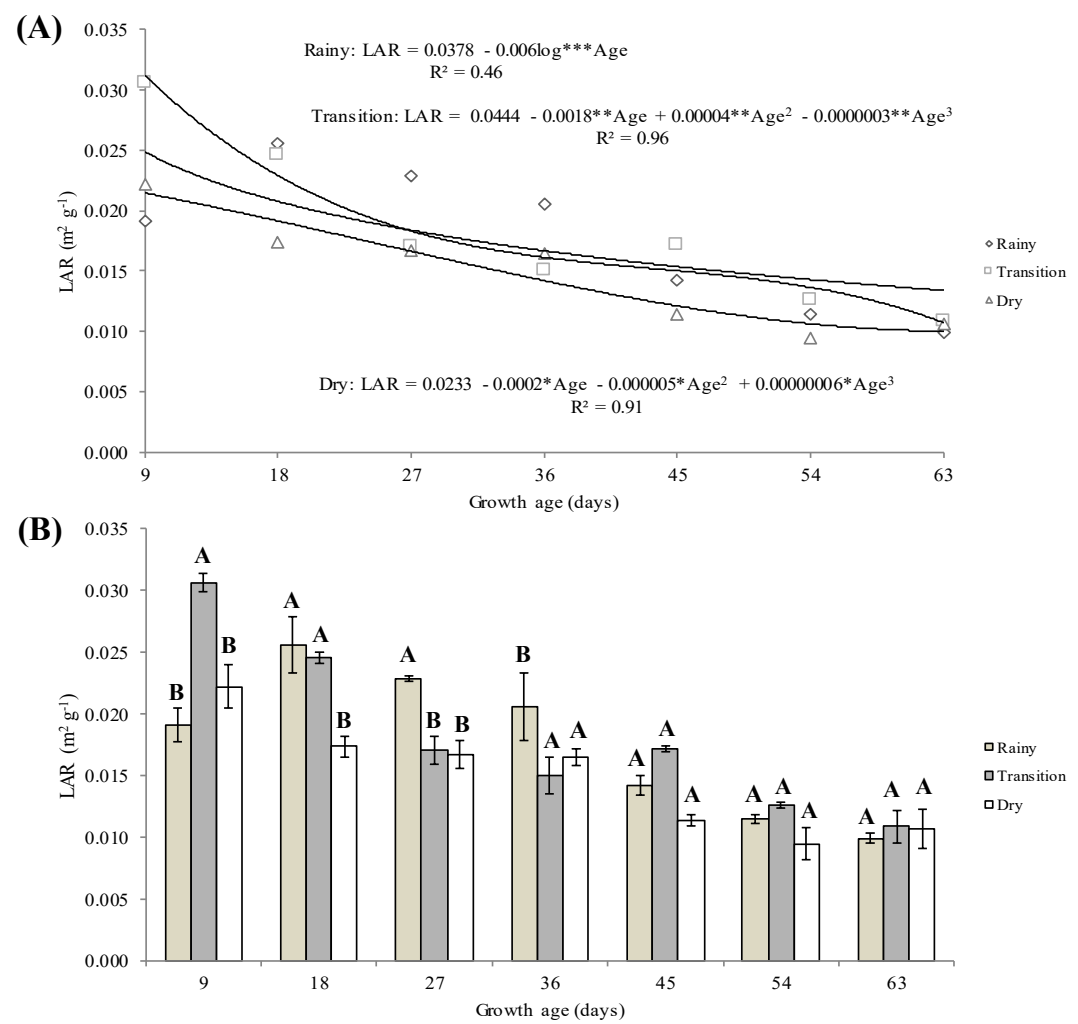

Figure 4. Leaf area ratio (LAR); coefficient of determination $\left(\mathrm{R}^{2}\right)$, significant at the level of $0.1 \%(* * *), 1 \%(* *), 5 \%(*)$. Means followed by the same uppercase letters in the 
same age do not differ $(\mathrm{p}>0.05)$ by the Tukey's test. Means followed by the same lowercase letters in different ages do not differ $(p>0.05)$ by the Tukey's test.

The reduction of LAR as a function of growth ages in all growing seasons can be attributed to the dynamics of the growth pattern with changes in source/drainage relations along the growth and development cycle of the forage plant (COSTA et al. 2012; LOPES et al., 2013). The elephant grass $\mathrm{cv}$. Roxo gradually reduced the investment of photoassimilates in the production of leaf blades, directing them to other plant organs, probably to the component stem and root system, in the rainy and dry seasons, respectively. The considerable reduction of LAR in the dry season in comparison to the other seasons is believed to be caused by the negative effects of the water deficit on the photosynthetic leaf area, such as reduction of leaf elongation and increase in leaf senescence (PEZZOPANE et al., 2015; NXELE et al., 2017). This hypothesis is corroborated by the high correlation $(\mathrm{r}=0.93, \mathrm{p}<0.05)$ between LAR and SLA (the morphological component of LAR) and the low, non-significant correlation $\quad(r=0.04, \quad p=0.431)$ between LAR and LWR (the physiological component of LAR).

Considering the effect of the growing season, it was verified that there was a higher LAR in the rainy season until age 36 DAC, believed to be caused by the water availability (Figure 1) together with the nutritional effect, especially the beneficial action of the nitrogen provided through nitrogen fertilisation, which potentiated the increase of useful leaf area in the production of forage biomass. From 27 DAC, the LAR did not differ $(p>0.05)$ between transition and dry seasons, and from $45 \mathrm{DAC}$, no difference $(p>0.05)$ was observed between seasons (Figure 4B).

The answer under consideration indicates that elephant grass cv. Roxo had its leaf area and total forage biomass reduced in similar proportions. It is possible to infer that the forage plant was efficient in the use of the rainfall water in the carbon assimilation, because despite the water deficit (Figure 1) and its negative effects on the leaf biomass flow, the forage plant managed to assimilate the same amount of carbon per unit of leaf area (Figure 4B).

The net assimilation rate did not adjust to the models tested for rainy and transition seasons (Figure 5A). With the advancement of the canopy age, there is a reduction of liquid photosynthesis and increase of respiration, causing a gradual reduction in the net assimilation rate (NAR), as documented by Cutrim et al. (2014). In the present study, an oscillation in NAR was observed throughout the growth ages, demonstrating the plasticity of elephant grass cv. Roxo with regard to carbon assimilation, conditioned by the occurrence of rainfall (Figure 1, Figure 5A). The rainfall was probably the main abiotic factor modulating the growth of elephant grass cv. Roxo in the present study, since most soil chemical attributes remained similar in the three growing seasons (Table 1). 
http//dx.doi.org/10.1590/S1519-9940210122020
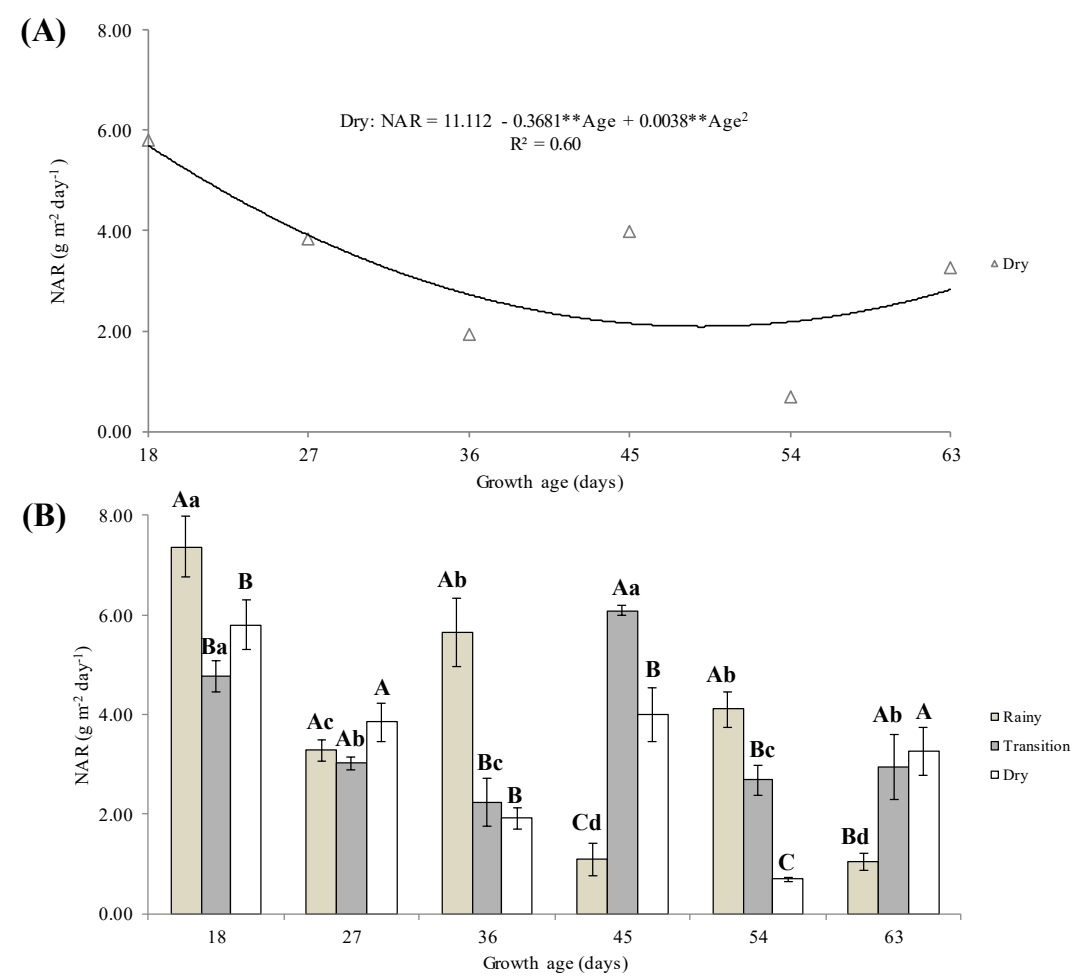

Figure 5. Net accumulation rate (NAR); coefficient of determination $\left(\mathrm{R}^{2}\right)$, significant at the level of $1 \%(* *)$. Means followed by the same uppercase letters in the same age do not differ $(p>0.05)$ by the Tukey's test. Means followed by the same lowercase letters in different ages do not differ $(p>0.05)$ by the Tukey's test.

In the rainy season, NAR presented an average of $3.73 \pm 2.50 \mathrm{~g} \mathrm{~m}^{-2}$ day $^{-1}$ (Figure 5B). It should be noted that the high oscillation in NAR may represent compensatory growth of elephant grass cv. Roxo, as it expressed its genetic potential, presenting a linear increase of biomass until age $63 \mathrm{DAC}$ $\left(11,653 \mathrm{~kg} \mathrm{DM} \mathrm{ha}^{-1}\right.$, with a height of $1.77 \mathrm{~m}$ ) at that time, as documented by Maranhão et al. (2018b).

The lowest NAR values observed at the end of the forage plant cycle, at 45 $\left(1.10 \mathrm{~g} \mathrm{~m}^{-2}\right.$ day $\left.^{-1}\right)$ and $63 \mathrm{DAC}$ $\left(1.04 \mathrm{~g} \mathrm{~m}^{-2}\right.$ day $\left.^{-1}\right) \quad$ (Figure 5B), were probably due to mutual shading of leaf blades, and this hypothesis was corroborated by the progressive reduction of LAR in the rainy season (Figure 4A). The increase of NAR at
54 DAC can be attributed to the rainfall (Figure 1), which possibly stimulated the biomass flow in the leaf fraction, due to the favouring of leaf elongation and the appearance of young leaf blades with high photosynthetic capacity, potentiating NAR, despite the advancement in the age of the canopy. Despite the low accumulated rainfall during the transition period $(17.3 \mathrm{~mm})$, elephant grass cv. Roxo presented a mean NAR of $3.63 \pm 1.48 \mathrm{~g} \mathrm{~m}^{-2}$ day $^{-1}$, similar to that quantified in the rainy season $\left(3.73 \pm 2.50 \mathrm{~g} \mathrm{~m}^{-2} \mathrm{day}^{-1}\right)$. The recorded result indicates that elephant grass cv. Roxo efficiently used the abiotic growth factors available at that time, probably by exploring the residual soil moisture, and such a hypothesis 
was corroborated by the LWR response at that time (Figure 3).

A quadratic adjustment in the NAR of elephant grass cv. Roxo was observed in the dry season, being minimised at 48.4 DAC $\left(2.20 \mathrm{~g} \mathrm{~m}^{-2}\right.$ day $\left.^{-1}\right) \quad$ and subsequently increasing up to $3.00 \mathrm{~g} \mathrm{~m}^{-2}$ day $^{-1}$ at 63 DAC (Figure 5A). The observed response was due to the rainfall that occurred at 54 and $63 \mathrm{DAC}$ (Figure 1), indicating that the limitation for carbon assimilation was probably stomatal because of the low moisture level in the soil, as with the resumption of rainfall NAR increased (ARAÚJO et al., 2010).

Regarding the effect of the growing seasons, NAR varied according to the growth age (Figure 5B). Considering the transition and dry seasons, it is important to note that the NAR of elephant grass cv. Roxo did not differ $(p>0.05)$ up to $36 \mathrm{DAC}$, despite the difference in accumulated rainfall up to this age $(17.30$ and $0.00 \mathrm{~mm}$ accumulated in the respective seasons). This response makes it possible to infer that the forage plant was efficient in the use of water present in the system (via rainfall or residual soil moisture) for carbon assimilation.

It is noteworthy that, despite the long water deficit in the dry season
(Figure 1), elephant grass cv. Roxo was able to acclimatise and preserve its photosynthetic apparatus, since carbon assimilation was resumed (63 DAC) after rainfall at the end of the dry season (Figure 5B).

The relative growth rate (RGR) in the rainy season did not fit the models tested as a function of the growth ages, with a mean value of $0.0075 \pm 0.0037 \mathrm{~g} \mathrm{~g}^{-1} \mathrm{day}^{-1}$. As in the transition and dry seasons, RGR adjusted to the third-degree model, varying from 0.0126 to $0.0077 \mathrm{~g} \mathrm{~g}^{-1}$ day $^{-1}$ in the transition season and 0.0098 to $0.0064 \mathrm{~g} \mathrm{~g}^{-1}$ day $^{-1}$ in the dry season, at ages 18 and 63 DAC, respectively (Figure 6A).

The RGR tends to reduce as the forage plant grows (BENINCASA, 2003). In the present study, RGR oscillation was observed with the advancement of growth age for all growing seasons (Figure 6A). The observed growth dynamics is directly related to the resumption of increased carbon assimilation in response to favourable soil moisture conditions due to the occurrence of rainfall (Figure 1). This response is supported by the high correlation between RGR and NAR in the transition $(r=0.90, p<0.0001)$ and dry $(r=0.94, p<0.0001)$ seasons. 


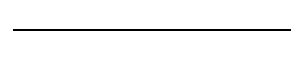
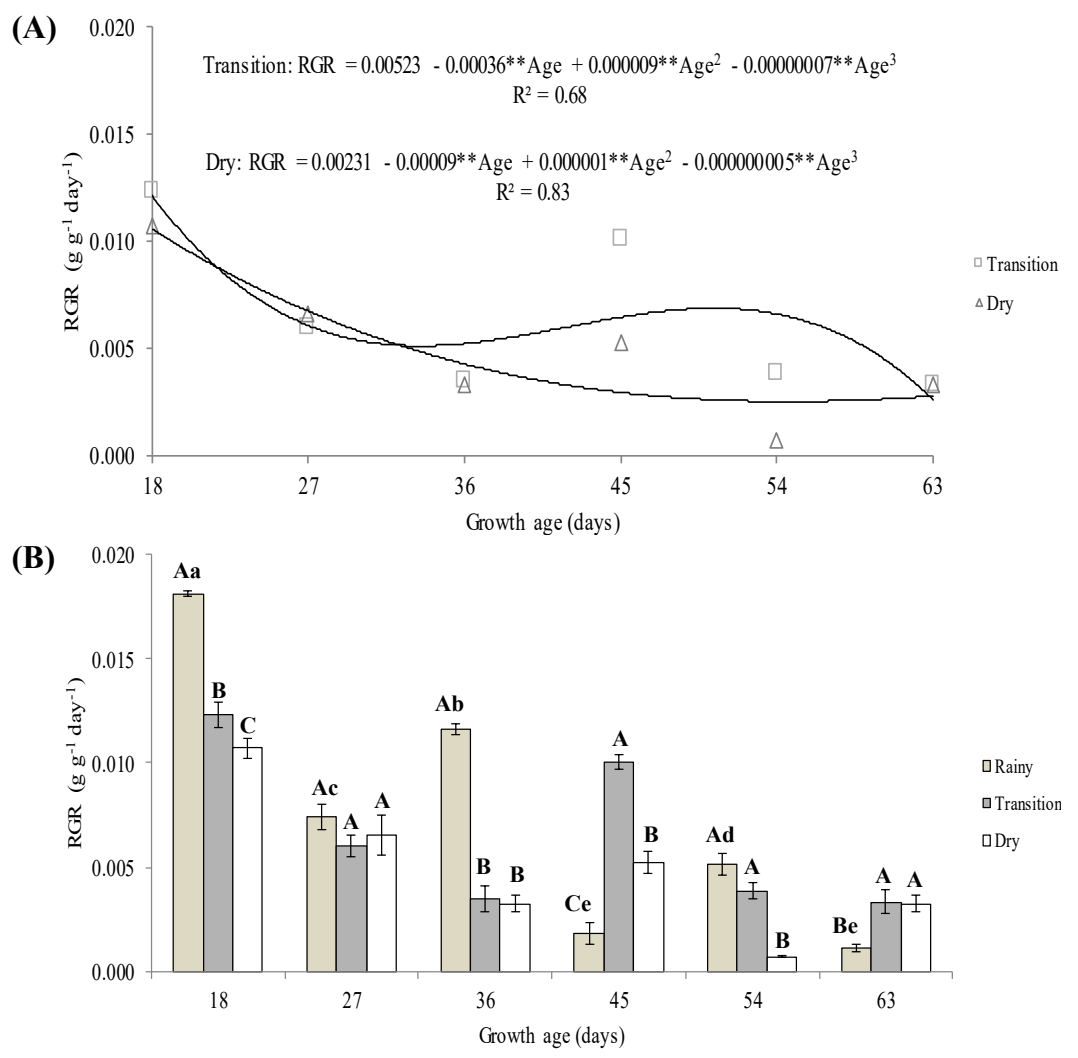

Figure 6. Relative growth rate (RGR); coefficient of determination $\left(\mathrm{R}^{2}\right)$, significant at the level of $1 \%(* *)$. Means followed by the same uppercase letters in the same age do not differ $(p>0.05)$ by the Tukey's test. Means followed by the same lowercase letters in different ages do not differ $(p>0.05)$ by the Tukey's test.

The RGR consists of the biomass increment per unit of pre-existing biomass and can be used to indicate the growth efficiency of the forage plant (BENINCASA, 2003). Considering the growing season factor, it was found that the RGR did not differ $(\mathrm{p}>0.05)$ between seasons at age 27 DAC and did not differ between transition and dry seasons at ages 36 and 63 DAC (Figure 6B).

The observed results indicate that elephant grass cv. Roxo maintained its biomass-increasing efficiency during some growth ages, despite the difference in accumulated rainfall between the growing seasons (373.3, 17.3 and $9.60 \mathrm{~mm}$ for rainy, transition and dry seasons, respectively) and the prolonged water deficit over the experimental period (Figure 1).

The growth indexes of elephant grass cv. Roxo are modified by the growth ages and seasons. The rates of net assimilation and relative growth resume with the occurrence of rainfall, regardless of the growth stage of the vegetative phase of the elephant grass cv. Roxo growth cycle. Elephant grass cv. Roxo presents resilience to water deficit, confirming the compensatory growth potential of this forage plant facing seasonal rainfall precipitation.

\section{REFERENCES}

ARAÚJO, S.A.C. \& DEMINICIS, B.B. Fotoinibição da Fotossíntese. Revista 
Brasileira de Biociências [online], v.7, n.4, p.463-472, 2009.

ARAÚJO, S.A.C.; VASQUEZ, H.M.; CAMPOSTRINI, E. NETTO, A.T.; DEMINICIS, B.B.; LIMA, E.S. Características fotossintéticas de genótipos de capim-elefante anão (Pennisetum purpureum Schum.), em estresse hídrico. Acta Scientiarum Animal Sciences [online], v.32, n.1, p.1-7, 2010.

BENINCASA, M.M.P. Análise de crescimento de plantas: noções básicas. Jaboticabal: FUNEP, 2003. 42 p.

COMISSÃO DE FERTILIDADE DO SOLO DO ESTADO DE MINAS GERAIS (CFSEMG). Recomendações para uso de corretivos e fertilizantes em Minas Gerais - $5^{\text {a }}$ Aproximação. 5. Ed. Viçosa: UFV, 1999. 359 p.

COSTA, J.P.R.; BRITO, L.F.; VIEIRA, L.D.C.; MEISTER, N.C.; MACEDO, C.H.O.; ALVES, P.L.C.A.; RUGGIERI, A.C. Análise de crescimento de dois cultivares de Brachiaria brizantha (A. Rich.) Stapf. (Poaceae). Biotemas [online], v.25, n.1, p.17-22, 2012.

CUTRIM JUNIOR, J.A.A.; BEZERRA, A.P.A.; FARIAS, S.F.; AQUINO, R.M.S.; SOMBRA, W.A.; ANDRADE, R.R.; CÂNDIDO, M.J.D.

Morfofisiologia do capim-tifton 85 manejado intensivamente sob corte. Acta Tecnológica [online], v.9, n.1, p.62-69, 2014.

DARTORA, J.; GUIMARÃES, V.F.; ECHER, M.M.; PAULETTI, D.R.; MARINI, D. Análise de crescimento e produtividade do pakchoi cultivado sob diferentes doses de nitrogênio. Revista Ceres [online], v.60, n.4, p.498-504, 2013.

DONG, X.; PATTON, J.; WANG, G.; NYREN, P.; PETERSON, P. Effect of drought on biomass allocation in two invasive and two native grass species dominating the mixed-grass Prairie. Grass and Forage Science [online], v.69, p.160-166, 2012.

INTERGOVERNMENTAL PANEL ON CLIMATE CHANGE - IPCC, Working Group II Report "Climate Change 2014:Impacts, Adaptation and Vulnerability" Disponível em: $<$ https://www.ipcc.ch/report/ar5/wg2/>

KÖPPEN, W. Das geographisca System der Klimate. Gebr, Borntraeger, 1936. 1-44p.

LOPES, M.N.; POMPEU, R.C.F.F.; SILVA, R.G.; FILHO, J.G.L.R.; BESERRA, L.T.; LACERDA, C.F. Trocas gasosas e índices de crescimento em capim-braquiária manejado sob lâminas de irrigação e idades de crescimento. Revista Agro@mbiente [online], v.7, n.1, p.10-17, 2013.

MARANHÃO, T.D.; CÂNDIDO, M.J.D.; LOPES, M.N.; POMPEU, R.C.F.F.; CARNEIRO, M.S.S.; FURTADO, R.N.; SILVA, R.R.; SILVEIRA, F.G.A. Biomass components of Pennisetum purpureum cv. Roxo managed at diferent growth ages and seasons. Revista Brasileira Saúde e Produção Animal [online], v.19, n.1, p.11-22, 2018 b.

MARANHÃO, T.D.; CÂNDIDO, M.J.D.; SOARES, I.; LOPES, M.N.; SILVA, R.R.; POMPEU, R.C.F.F.; 
LACERDA, G.F.; SOUSA, W.N. Accumulation and partition of macronutrients in Pennisetum purpureum $\mathrm{cv}$. Roxo managed under different growth ages and seasons.

Revista Brasileira de Saúde e Produção Animal [online], v.19, n.3, p.223-240, 2018a.

MARENGO, J.A.; Água e mudanças climáticas. Estudos avançados [online], v.22, n.63, 2008.

MOREIRA, J.A.S.; FAGUNDES, J.L.; MISTURA, C.; LEMOS, N.L.S.; MOREIRA, J. N.; BACKES, A.A.; MORAIS, J.A.S.; OLIVEIRA, V.S.; MOREIRA, A.L. Características morfogênicas, estruturais e produtivas de acessos de capim-buffel. Semina:

Ciências Agrárias [online], v.36, n.1, p.391-400, 2015.

NXELE, X.; KLEIN, A.; NDIMBA, B.K.. Drought and salinity stress alters ROS accumulation, water retention, and osmolyte content in sorghum plants.

South African Journal of Botany [online], v.108, p.261-266, 2017.

PENNISI, E. The Blue Revolution, Drop By Drop, Gene by

Gene.SCIENCE [online], v.320, 2008.

PEZZOPANE, C.G.; SANTOS, P.M.; CRUZ, P.G.; ALTOÉ, J.; RIBEIRO, F.A.; VALLE, C.B. Estresse por deficiência hídrica em genótipos de Brachiaria brizantha. Ciência Rural [online], v.45, n.5, 2015.

PINCELLI, R.P.; SILVA, M.A. Alterações morfológicas foliares em cultivares de cana de-açúcar em resposta à deficiência hídrica.
Bioscience Journal [online], v.28, n.4, p.546-556, 2012.

\section{SAEG-Sistema para Análises}

Estatísticas, Versão 9.1. Fundação

Arthur Bernardes -UFV- Viçosa, 2007.

SANTOS, H.G. dos; JACOMINE, P.K.T.; ANJOS, L.H.C. dos; OLIVEIRA, V.A. de; LUMBRERAS, J.F.; COELHO, M.R.; ALMEIDA, J.A. de; CUNHA, T.J.F.; OLIVEIRA, J.B. de. Sistema brasileiro de classificação de solos. 3.ed. rev. e ampl. Brasília: Embrapa, 2013. 353p.

SANTOS, M.E.R.; AQUINO, R.F.S.F.; ROMÃO, M.C.; Determinantes da morfologia da lâmina foliar de capimelefante. Enciclopédia Biosfera [online], v.6, n.11, p.1-10, 2010.

TAIZ, L.; ZEIGER, E.; MØLLER, I.M.; MURPHY, A. Fisiologia e

Desenvolvimento Vegetal. $6^{\circ} \mathrm{Ed}$.

Editora Artmed, 2017. 888p. 